\title{
Students' Milk Consumption Patterns at Erzincan Binali Yildirim University
}

\author{
Hediye KUMBASAROĞLU ${ }^{1}$, Tuğba EREM KAYA ${ }^{2}$
}

\begin{abstract}
The present study was conducted on 380 students studying at Erzincan Binali Yildirim University, $57.40 \%$ of whom are male and $42.60 \%$ female related to their consumption behavior of drinking milk. For analysis of the data, complementary statistics and chi-square test were used. The results of the survey suggest that $21.10 \%$ of the students regularly consume milk while $78.90 \%$ of the students irregularly drink milk. Among the reasons why the students dislike drinking milk are its taste (37.67\%) with a high percentage and smell (30.66\%) affecting the students? The percentage of those who do not drink milk for allergic reasons is $4.67 \%$. A significant difference was also reported between the reasons for dislike drinking milk and gender $(\mathrm{p}<0.05)$. It was found that $27.89 \%$ of the respondents paid attention to the expiry date during shopping and $39.21 \%$ preferred one percent milk. $67.37 \%$ of the students reported that they preferred markets for buying milk. It was found that gender, nourishing property, fat level, price and milk consumption patterns in the market played role in the participants' preference of milk consumption.
\end{abstract}

Keywords: Milk, Chi-Square Test, Consumption Habits, Erzincan.

\footnotetext{
${ }^{1}$ Hediye KUMBASAROĞLU (Orcid ID: 0000-0003-0266-3775), Erzincan Binali Y1ldırım University, Vocational School, Department of Marketing and Foreign Trade, Marketing Program, Erzincan/Turkey,

2 Tuğba EREM KAYA (Orcid ID: 0000-0001-5399-4828), Governorship of Bursa, Provincial Directorate of Environment and Urbanization, Bursa/Turkey

*Sorumlu Yazar/Corresponding Author: Hediye KUMBASAROĞLU, e-mail: hediye.kumbasaroglu@erzincan.edu.tr 


\section{INTRODUCTION}

Milk has an important place for bone development in terms of nutrients it contains in all periods from infancy to old age. It is an important source for many nutrients including protein, calcium, phosphorus, vitamin B2 and vitamin B12. In this respect, it is a miraculous food that all age groups, especially children, young people and adults, should consume.

Milk consumption is considered as an indicator of country development. Consumption values of milk and dairy products are quite high in countries that are adequately fed and healthy. The most efficient form of milk is to use it as drinking milk (Cetinkaya, 2010).

Turkey is the world's 10th largest producer with an annual production of 22 million tons of milk. Total milk production, which was 15.10 million tons in 2011, increased to 20.12 million tons in 2018 (Anonymous, 2019a). The National Milk Council Report published every two years by FAO on the global food market includes trade data on the basis of the amount of raw milk produced and products produced worldwide. Accordingly, FAO estimates that world total milk production in 2018 is 829 million tons. While the region with the largest shareholder in the increase in the world's total milk production is Asia with an additional 9.7 million tons of milk production compared to previous year, the highest increase in the production of milk in terms of country have been reported to be India, China, Turkey and Pakistan in the report. When the amount of raw milk production and the population data for the same year published annually by Turkish Statistical Institution (TSI) were handled, ignoring the milk and milk products import and export figures, the milk consumption per person was found to be $270 \mathrm{~kg}$ of milk. Income growth, urbanization and increased demand as a result of that fact that individuals make more conscious choices about nutrition has led to the increase in the amount of milk and milk products produced in modern facilities. Considering the milk quantity except registered milk production quantity, foreign trade data and the amount of milk collected by the integrated milk companies, consumption of milk per person is estimated to be about $41.50 \mathrm{~kg}$ a year (Anonymous 2019b). Although Turkey has an important place in the world, it is way back in terms of milk consumption.

University life, in which students satisfy their nutritional needs, forms the basis of one's future diet. Generally, not having breakfast or lunch and fast food consumption are the common eating behaviors seen among university students, which causes nutritional disorders in students. It is very important to determine the consumption behaviors of milk and dairy products which are very important for adequate and balanced nutrition of university students and to take necessary precautions.

It is necessary to reveal the consumption habits of people and determine the effect of income levels on consumption amounts in order to establish a healthy society. (Tarakçı et al., 2003).

In Turkey, it has been reported in several studies that milk is not sufficiently consumed. At the universities in the cities like Kars (Cetinkaya, 2010), Isparta (Simsek and Acikgoz, 2011), Edirne (Onurlubas et al., 2015), Gumushane (Sahinoz and Ozdemir, 2017), Bitlis (Yalcin and Argun, 2017) and Kayseri (Para et al., 2018), surveys have been conducted to reveal that university students' consumption of milk and dairy products is not at an expected level. To determine the factors that affect the consumption of milk and dairy products, surveys have been administered in the provinces like Istanbul (Simsek et al., 2005), Elazig (Seker et al., 2012), Ordu (Tarakci et al., 2015), Southern Marmara Region (Niyaz and İnan, 2016), Istanbul, Ankara, Izmir (Onurlubas and Cakırlar, 2016).

This study was conducted on the students' milk consumption behaviors vis-à-vis gender studying at Erzincan Binali Yildirim University in 2018-2019 academic year in order to the fill the gap in the literature. 


\section{MATERIAL AND METHODS}

The material of this study is composed of the data obtained from face-to-face interviews with the students selected by sampling method studying at Erzincan Binali Yildirim University in 2019 in order to determine their knowledge and milk consumption habits. The surveys were conducted on the students studying at different schools of Erzincan Binali Yildirim University (Education, Arts and Science, Economics and Administrative Sciences, Theology, Engineering, Pharmacy, Medicine, Law, Dentistry, Vocational Schools and Colleges (Table 1). To determine the appropriate sample, 20 students were given questionnaires beforehand. Sample size was found based on this pilot survey.

Table 1. The number of students at Erzincan Binali Yildirim University

\begin{tabular}{lcc}
\hline School and college & Number & \% \\
\hline School of education & 3334 & 15.61 \\
School of arts and science & 1558 & 7.29 \\
School of economics and administrative sciences & 2159 & 10.11 \\
School of theology & 721 & 3.38 \\
School of engineering & 1238 & 5.80 \\
School of pharmacy & 253 & 1.18 \\
School of medicine & 373 & 1.75 \\
School of law & 1521 & 7.12 \\
School of dentistry & 63 & 0.29 \\
Vocational schools & 8184 & 38.31 \\
Colleges & 1956 & 9.16 \\
\hline Total & $\mathbf{2 1 ~ 3 6 0}$ & $\mathbf{1 0 0 . 0 0}$ \\
\hline
\end{tabular}

In this study, sample size was determined by non-clustered single-stage random probability sampling method based on the main mass ratios (Collins, 1986; Karakaya and Akbay, 2013).

$\mathrm{n}=\mathrm{t}^{2} *[1+(0.02)(\mathrm{b}-1)]^{*}(\mathrm{p} * \mathrm{q}) /(\mathrm{e})^{2}$

Here; $\mathrm{n}$ is for sample size; $\mathrm{t}$ : $95 \%$ table value depending on the level of importance; $\mathrm{b}$ : sample stage (as it is single stage, it is taken as 1); p: probability of realization of the case examined among the main mass (the ratio of those consuming milk regularly); q: the probability of non-realization of the case examined (1-p), (the ratio of those not consuming milk regularly); e: Accepted margin of error (in this study margin of error is taken as $5 \%$ ). In the equation, if $b=1$, the equation becomes as follows: $\mathrm{n}=\mathrm{t}^{2} *(\mathrm{p} * \mathrm{q}) /(\mathrm{e})^{2}$

By means of the pilot survey conducted before, it was found that $30 \%$ of the students regularly drank milk while $70 \%$ did drink milk irregularly. This percentage gave us the maximum sample size considering the margin of error. In the study $5 \%$ was accepted as the margin of error. Accordingly, the sample size was found by means of the following calculation. $n=(1.96) 2 .(0.30) \cdot(0.70) /(0.05) 2=$ 322 students.

Sample size was determined as 322. Considering that there will be lost values in the survey, the number of surveys has been completed to 380 to represent female and male students.

These 380 students were randomly selected out of the students studying at various schools of Erzincan Binali Yildirim University. The data obtained from the study were examined under two groups as male and female students. The data collected by means of the surveys responded by the students were evaluated by using the chi-square statistical tests of SPSS 22.00 statistical package program.

\section{RESULTS AND DISCUSSION}

\section{Socio-Economic Situation of the Students}

162 female and 218 male students, totally 380 (Table 2) participated in the surveys, of whom 145 study at vocational school (38.16\%), 55 at the school of education (14.47\%), 26 at the school of Arts 
and Science (6.84\%), 46 at the school of engineering (12.11\%), 25 at Law (6.58\%), 36 at Economics and Administrative Sciences (9.47\%), 12 at the Theology (3.16\%), 11 at the Schools related to Health Sciences (Medicine, Pharmacy and Dentistry) (2.89\%) and 24 at the College (6.32\%) (Table 3).

Table 2. Number of students' vs gender

\begin{tabular}{lcc}
\hline \multicolumn{3}{c}{ The number of respondents } \\
\hline & Number & \% \\
\hline Male & 218 & 57.40 \\
Female & 162 & 42.60 \\
Total & $\mathbf{3 8 0}$ & $\mathbf{1 0 0 . 0 0}$ \\
\hline
\end{tabular}

Table 3. The number of surveys vs schools

\begin{tabular}{lcc}
\hline School and college & Number & \% \\
\hline School of education & 55 & 14.47 \\
School of arts and science & 26 & 6.84 \\
School of engineering & 46 & 12.11 \\
School of law & 25 & 6.58 \\
School of economics and administrative sciences & 36 & 9.47 \\
School of theology & 12 & 3.16 \\
Health sciences (medicine, pharmacy, dentistry) & 11 & 2.89 \\
College & 24 & 6.32 \\
Vocational school & 145 & 38.16 \\
\hline Total & $\mathbf{3 8 0}$ & $\mathbf{1 0 0 . 0 0}$ \\
\hline
\end{tabular}

$26.84 \%$ of the students stay with their parents; $54.21 \%$ at university housing, $18.16 \%$ on their own, $1.05 \%$ with relatives (Table 4 ).

Fathers' jobs of the respondents were found as follows: $24.47 \%$ civil servant, $21.05 \%$ retired, $20.00 \%$ worker, $18.16 \%$ artisan, $11.31 \%$ farmer and $5 \%$ unemployed (Table 4 ).

In addition, monthly income of $58.68 \%$ of the student parents having a direct effect on consumption is more than 3000 while that of $13.69 \%$ is less than 1500 (Table 4).

Monthly average revenue of $44.74 \%$ of the students is less than $500 \mathrm{E}$ and that of $16.31 \%$ of the students is more than 1000 (Table 4).

\section{Students' Consumption of Dairy Products}

$78.90 \%$ of the students answered "No" to the question "Do you have the habit of drinking milk regularly every day?", $21.10 \%$ answered "Yes". $25.30 \%$ of $21.10 \%$ of those stating regular consumption of milk is female and $17.89 \%$ is male. Statistically significant difference was observed between male and female students in terms of regular consumption of milk $(\mathrm{p}<0.05)$ (Table 5).

In this study, it was seen that students consume $4.69 \mathrm{lt}$ of milk a month and female students consume $3.93 \mathrm{lt} / \mathrm{month}$ and male students $5.25 \mathrm{lt} / \mathrm{month}$. In terms of milk consumption habits, although female students consume milk more regularly, it was observed that the amount of milk consumed is less than that of the male students. In a study conducted by Yalcinkaya (1999) on the drinking milk habits and the factors that have an impact on them in the province of Tekirdag, families were reported to consume less than a kilo of milk daily. In the study by Simsek et al. (2005) in Istanbul, milk consumption per capita was reported to be 34lt/year. In the research conducted by Tarakci et al. (2003) to reveal socioeconomic situation of the students, their drinking milk habits and knowledge on nutritional benefits of milk, bachelor's degree students at Yuzuncu Yil University were reported to consume milk in average $3.7 \mathrm{lt} / \mathrm{month}$. In a study by Carol et al. (2015), per capita milk consumption in Canada was reported to be $213 \mathrm{~mL}$ per day. 
The researches on milk consumption habits of people in Turkey reveal that milk is not sufficiently consumed. The present study confirmed that students' milk consumption level is lower than expected.

Table 4. Socio-economic situation of the students

Places where students stay

\begin{tabular}{|c|c|c|}
\hline & Number & $\%$ \\
\hline University housing & 206 & 54.21 \\
\hline With parents & 101 & 26.58 \\
\hline Student house & 69 & 18.16 \\
\hline With relative & 4 & 1.05 \\
\hline \multicolumn{3}{|c|}{ Job of the householder } \\
\hline Civil servant & 93 & 24.47 \\
\hline Retired & 80 & 21.05 \\
\hline Worker & 76 & 20.00 \\
\hline Artisan & 69 & 18.16 \\
\hline Farmer & 43 & 11.31 \\
\hline Unemployed & 19 & 5.00 \\
\hline \multicolumn{3}{|c|}{ Monthly income of the householder (f) } \\
\hline Less than 1500 & 52 & 13.69 \\
\hline Between 1500-3000 & 105 & 27.63 \\
\hline More than 3000 & 223 & 58.68 \\
\hline \multicolumn{3}{|c|}{ Monthly revenue of the students (E) } \\
\hline Less than 500 & 170 & 44.74 \\
\hline Between 500-1000 & 148 & 38.95 \\
\hline More than 1000 & 62 & 16.31 \\
\hline Total & 380 & 100.00 \\
\hline
\end{tabular}

Table 5. Students regular consumption of milk

\begin{tabular}{lcccccc}
\hline & \multicolumn{2}{c}{ Female } & \multicolumn{2}{c}{ Male } & \multicolumn{2}{c}{ Total } \\
\hline Milk regularly & Number & $\mathbf{\%}$ & Number & $\mathbf{\%}$ & Number & $\mathbf{\%}$ \\
\hline Consumed & 41 & 25.30 & 39 & 17.89 & 80 & 21.10 \\
Not consumed & 121 & 74.70 & 179 & 82.11 & 300 & 78.90 \\
\hline Total & $\mathbf{1 6 2}$ & $\mathbf{1 0 0 . 0 0}$ & $\mathbf{2 1 8}$ & $\mathbf{1 0 0 . 0 0}$ & $\mathbf{3 8 0}$ & $\mathbf{1 0 0 . 0 0}$ \\
\hline \multicolumn{7}{c}{$X^{2}=3.078, s d=1, p<0.05(0.042)$} \\
\hline
\end{tabular}

When the reasons for drinking milk were asked to those who regularly consumed milk, it was found that $61.25 \%$ of the students consumed milk for the nutritional reasons, $25.00 \%$ as a habit, $3.75 \%$ because of medical disorder. On the other hand, $10.00 \%$ stated that they did not consume milk because they did not have any habit and no specific reason was reported. In the chi-square analysis, it was found that there was a statistically significant difference between the genders in terms of regular milk consumption $(\mathrm{p}<0.05)$ (Table 6).

In the study conducted by Cetinkaya (2010) on the determination of milk and dairy product consumption of students at Kafkas University, $46.00 \%$ of the students stated that they consumed milk for nutritional reasons while $25.30 \%$ drew attention to the need of vitamin, calcium and protein milk provided.

When those not consuming milk regularly were asked the reason, $37.67 \%$ stated because of its taste, $30.66 \%$ for its smell, $4.67 \%$ for the discomfort it causes and $27.00 \%$ just because they were not 
used to drinking milk. Statistical difference was found between the reasons for drinking and not drinking milk and gender $(\mathrm{p}<0.05)$ (Table 6).

Table 6. Regular drinking milk of the students

\begin{tabular}{|c|c|c|c|c|c|c|}
\hline \multicolumn{7}{|c|}{ Gender } \\
\hline & \multicolumn{2}{|c|}{ Female } & \multicolumn{2}{|c|}{ Male } & \multicolumn{2}{|c|}{ Total } \\
\hline Reason for drinking milk & Number & $\%$ & Number & $\%$ & Number & $\%$ \\
\hline Nutritional & 21 & 51.22 & 28 & 71.80 & 49 & 61.25 \\
\hline Habit & 12 & 29.27 & 8 & 20.51 & 20 & 25.00 \\
\hline Discomfort & 3 & 7.32 & 0 & 0.00 & 3 & 3.75 \\
\hline Other & 5 & 12.19 & 3 & 7.69 & 8 & 10.00 \\
\hline Total & 41 & 100.00 & 39 & 100.00 & 80 & 100.00 \\
\hline \multicolumn{7}{|c|}{$X^{2}=17.448, s d=4, p<0.05(0.002)$} \\
\hline \multicolumn{7}{|c|}{ Reasons for not drinking milk } \\
\hline Smell & 39 & 32.23 & 53 & 29.61 & 92 & 30.66 \\
\hline Taste & 43 & 35.54 & 70 & 39.11 & 113 & 37.67 \\
\hline Allergy & 14 & 11.57 & 0 & 0.00 & 14 & 4.67 \\
\hline Other & 25 & 20.66 & 56 & 31.28 & 81 & 27.00 \\
\hline Total & 121 & 100.00 & 179 & 100.00 & 300 & 100.00 \\
\hline \multicolumn{7}{|c|}{$X^{2}=19.945, s d=4, p<0.05(0.001)$} \\
\hline
\end{tabular}

The students answered the question related to the nutritional benefits of milk as it is protein source with $26.58 \%$, gaining immunity with $15.52 \%$, vitamin and mineral source with $8.68 \%$, source of energy with $3.68 \%$, containing of all nutrients needed $36.58 \%$ and none with $2.11 \%$. No statistically significant difference was found between male and female students in terms of milk nutrition ( $>0.05$ ) (Table 7).

Table 7. Knowledge level of students on nutritional value of milk

\section{Gender}

Female

Male

Total

\begin{tabular}{lcccccc}
$\begin{array}{l}\text { What do you know about } \\
\text { nutritional value of milk? }\end{array}$ & Number & $\mathbf{\%}$ & Number & $\mathbf{\%}$ & Number & $\%$ \\
& & & & & & \\
\hline Protein & 44 & 27.16 & 57 & 26.15 & 101 & 26.58 \\
Fat & 9 & 5.56 & 12 & 5.50 & 21 & 5.53 \\
Lactose & 2 & 1.23 & 3 & 1.38 & 5 & 1.32 \\
Vitamin & 14 & 8.64 & 19 & 8.72 & 33 & 8.68 \\
Gives energy & 6 & 3.70 & 8 & 3.67 & 14 & 3.68 \\
Consolidates immunity & 27 & 16.67 & 32 & 14.68 & 59 & 15.52 \\
All & 56 & 34.57 & 83 & 38.07 & 139 & 36.58 \\
None & 4 & 2.47 & 4 & 1.83 & 8 & 2.11 \\
\hline Total & $\mathbf{1 6 2}$ & $\mathbf{1 0 0 . 0 0}$ & $\mathbf{2 1 8}$ & $\mathbf{1 0 0 . 0 0}$ & $\mathbf{3 8 0}$ & $\mathbf{1 0 0 . 0 0}$ \\
\hline \multicolumn{7}{c}{$s d=8, p>0.05(0.995)$} \\
\hline
\end{tabular}

Based on the answers given to the question in order to learn the consumption pattern of drinking milk, it was determined that $30.26 \%$ of the respondents preferred it cold, $24.21 \%$ hot, $12.37 \%$ with cacao, $8.68 \%$ with sugar, $6.58 \%$ in coffee, and $6.05 \%$ unsweetened. It is seen that male and female students consume milk more frequently. Statistically significant difference was found between male and female students' consumption patterns of milk. $(\mathrm{p}<0.05)($ Table 8$)$. 
Ayar and Demirulus (2000) in their study determined that rural students preferred to drink milk as hot and sweet, while urban students preferred milk cold. In a similar study by Kim et al. (1994) found that $59.5 \%$ of those who consumed whole milk prefer flavored whole milk.

Table 8. Milk consumption patterns of students.

\begin{tabular}{|c|c|c|c|c|c|c|}
\hline \multicolumn{7}{|c|}{ Gender } \\
\hline & \multicolumn{2}{|c|}{ Female } & \multicolumn{2}{|c|}{ Male } & \multicolumn{2}{|c|}{ Total } \\
\hline How you like milk & Number & $\%$ & Number & $\%$ & Number & $\%$ \\
\hline Hot & 30 & 18.52 & 62 & 28.44 & 92 & 24.21 \\
\hline Cold & 44 & 27.16 & 71 & 32.57 & 115 & 30.26 \\
\hline With sugar & 16 & 9.88 & 17 & 7.80 & 33 & 8.68 \\
\hline Without sugar & 7 & 4.32 & 16 & 7.34 & 23 & 6.05 \\
\hline With cacao & 29 & 17.90 & 18 & 8.26 & 47 & 12.37 \\
\hline Coffee & 14 & 8.64 & 11 & 5.05 & 25 & 6.58 \\
\hline Other & 5 & 3.09 & 9 & 4.13 & 14 & 3.69 \\
\hline No consumption at all & 17 & 10.49 & 14 & 6.42 & 31 & 8.16 \\
\hline Total & 162 & 100.00 & 218 & 100.00 & 380 & 100.00 \\
\hline \multicolumn{7}{|c|}{$X^{2}=17.517, s d=7, p<0.05(0.014)$} \\
\hline
\end{tabular}

When asked about the preferred fat level in milk, $39.21 \%$ of the students preferred one percent milk, $23.42 \%$ whole milk, and $19.47 \% 2$ percent and $8.95 \%$ skim milk. $45.68 \%$ of the students who preferred one percent milk are female and $34.41 \%$ are male students. Statistically significant difference was seen between fat level and gender $(p<0.05)$ (Table 9).

Table 9. Students preference of milk according to fat level

\begin{tabular}{lcccccc}
\hline & \multicolumn{2}{c}{ Female } & \multicolumn{2}{c}{ Male } & \multicolumn{2}{c}{ Total } \\
\hline Fat level preferred & Number & $\mathbf{\%}$ & Number & $\mathbf{\%}$ & Number & \% \\
\hline Whole & 25 & 15.43 & 64 & 29.36 & 89 & 23.42 \\
2 percent & 31 & 19.14 & 43 & 19.72 & 74 & 19.47 \\
1 percent & 74 & 45.68 & 75 & 34.41 & 149 & 39.21 \\
Skim & 14 & 8.64 & 20 & 9.17 & 34 & 8.95 \\
No consumption & 18 & 11.11 & 16 & 7.34 & 34 & 8.95 \\
\hline Total & $\mathbf{1 6 2}$ & $\mathbf{1 0 0 . 0 0}$ & $\mathbf{2 1 8}$ & $\mathbf{1 0 0 . 0 0}$ & $\mathbf{3 8 0}$ & $\mathbf{1 0 0 . 0 0}$ \\
\hline$X^{2}=12.232, s d=4, p<0.05(0.016)$ & & & & &
\end{tabular}

$28.16 \%$ of the students consumed milk in the evening, which was followed by the percentages $26.32 \%$ at bedtime and $17.89 \%$ in the morning. The percentage of those who consumed milk between meals was $12.11 \%$. Female students consumed milk in the evening $(29.63 \%)$ more than male students $(27.98 \%)$. No statistically significant difference was observed between the meals and male and female students' consumption of milk. ( $>>0.05$ ) (Table 10).

In their study, Şimşek and Açıkgöz (2011) found that $40.10 \%$ of the students consumed milk before bedtime, followed by in the evening $(25.30 \%)$ and between meals $(17.70 \%)$ and that the rate of those who consumed milk at breakfast was $14.50 \%$. They also detected that female students' consumption of milk $(21.00 \%)$ was higher than that of male students $(12.90 \%)$. 
Table 10. Periods of drinking milk of students

\begin{tabular}{lcccccc}
\hline & \multicolumn{3}{c}{ Gender } & \multicolumn{2}{c}{ Total } \\
\hline Period of drinking milk & Number & $\mathbf{\%}$ & Number & \% & Number & \% \\
\hline Morning & 24 & 14.82 & 44 & 20.18 & 68 & 17.89 \\
Noon & 9 & 5.56 & 8 & 3.67 & 17 & 4.47 \\
Evening & 48 & 29.63 & 59 & 27.07 & 107 & 28.16 \\
Before going to bed & 39 & 24.07 & 61 & 27.98 & 100 & 26.32 \\
Between meals & 21 & 12.96 & 25 & 11.47 & 46 & 12.11 \\
No consumption at al & 21 & 12.96 & 21 & 9.63 & 42 & 11.05 \\
\hline Total & $\mathbf{1 6 2}$ & $\mathbf{1 0 0 . 0 0}$ & $\mathbf{2 1 8}$ & $\mathbf{1 0 0 . 0 0}$ & $\mathbf{3 8 0}$ & $\mathbf{1 0 0 . 0 0}$ \\
\hline$X^{2}=4.096, s d=5, p>0.05(0.536)$ & & & & & \\
\hline
\end{tabular}

To the question asked to determine where the students got milk, they answered mostly $(67.37 \%)$ from the market, $12.63 \%$ produced themselves, $8.41 \%$ from the grocery, $7.63 \%$ from the street milkman. $69.75 \%$ of the students who bought milk from the market were female students and $65.60 \%$ were male students. No statistically significant difference was seen between male and female students in terms of places where they got milk ( $\mathrm{p}>0.05)$ (Table 11).

Sahin et al. (2001) suggested that markets were the most preferred stores. The rich variety, the diverse products, price comparability, product and service quality, easy return of defective goods were shown as among the most important factors in choosing the market.

Table 11. Distribution of markets students buy milk

\section{Gender}

\begin{tabular}{lcccccc}
\hline & \multicolumn{2}{c}{ Female } & \multicolumn{2}{c}{ Male } & \multicolumn{2}{c}{ Total } \\
\hline Where do you get milk? & Number & $\mathbf{\%}$ & Number & \% & Number & \% \\
\hline Market & 113 & 69.75 & 143 & 65.60 & 256 & 67.37 \\
Grocery & 11 & 6.79 & 21 & 9.63 & 32 & 8.42 \\
Milkman & 10 & 6.17 & 19 & 8.71 & 29 & 7.63 \\
Self-product & 22 & 13.58 & 26 & 11.93 & 48 & 12.63 \\
No milk at all & 6 & 3.71 & 9 & 4.13 & 15 & 3.95 \\
\hline Total & $\mathbf{1 6 2}$ & $\mathbf{1 0 0 . 0 0}$ & $\mathbf{2 1 8}$ & $\mathbf{1 0 0 . 0 0}$ & $\mathbf{3 8 0}$ & $\mathbf{1 0 0 . 0 0}$ \\
\hline
\end{tabular}

$X^{2}=2.161, s d=4, p>0.05(0.706)$

In order to determine the type of milk preferred by the students, $41.05 \%$ stated processed milk, $27.37 \%$ fruit milk and $18.69 \%$ unprocessed milk. While $38.89 \%$ of the female students preferred processed milk, this rate was $42.66 \%$ for male students. Statistically significant difference was found between the patterns of milk preferred by male and female students $(\mathrm{p}<0.05)$ (Table 12).

In the research conducted by Celik et al. (2005) in the province of Sanliurfa, $46.30 \%$ of consumers bought unprocessed milk while $53.70 \%$ preferred processed milk. In the study conducted by Karakaya and Akbay (2013), it was determined that approximately $26.50 \%$ of the families consumed unprocessed milk, $26.20 \%$ consumed pasteurized milk and $87.70 \%$ consumed sterilized milk. In the study conducted by Akbay and Tiryaki (2013) in Kahramanmaras, 57.00\% of consumers preferred unprocessed milk and $38.00 \%$ preferred processed milk. In the same study, nearly $50.00 \%$ of the participants regarded unprocessed milk as much healthier. 
Table 12. Types of milk students prefer

\begin{tabular}{lcccccc}
\hline & \multicolumn{3}{c}{ Gender } & \multicolumn{2}{c}{ Male } & \multicolumn{2}{c}{ Total } \\
\hline Type of milk consumed weekly & Number & \% & Number & \% & Number & \% \\
\hline Processed milk & 63 & 38.89 & 93 & 42.66 & 156 & 41.05 \\
Milk fruit & 56 & 34.57 & 48 & 22.02 & 104 & 27.37 \\
Lactose free milk & 6 & 3.70 & 14 & 6.42 & 20 & 5.26 \\
Unprocessed milk & 23 & 14.20 & 48 & 22.02 & 71 & 18.69 \\
No consumption & 14 & 8.64 & 15 & 6.88 & 29 & 7.63 \\
\hline Total & $\mathbf{1 6 2}$ & $\mathbf{1 0 0 . 0 0}$ & $\mathbf{2 1 8}$ & $\mathbf{1 0 0 . 0 0}$ & $\mathbf{3 8 0}$ & $\mathbf{1 0 0 . 0 0}$ \\
\hline$X^{2}=10.395, s d=4, p<0.05(0.034)$ & & & & & & \\
\hline
\end{tabular}

On the other hand, $38.68 \%$ of the students stated that milk is expensive. $37.63 \%$ of the students think that the price is reasonable. Only $5.00 \%$ of the students found that milk was cheap. Statistically significant difference was observed between milk price and gender $(\mathrm{p}<0.05)$ (Table 13).

In a similar study by Simsek et al. (2005), it was found that $2.00 \%$ of the university students pointed out that milk was cheap, $51.00 \%$ stated reasonable and $47.00 \%$ expensive.

Table 13. Students' opinions on milk price

\begin{tabular}{|c|c|c|c|c|c|c|}
\hline \multicolumn{7}{|c|}{ Gender } \\
\hline \multirow[b]{2}{*}{ Price } & \multicolumn{2}{|c|}{ Female } & \multicolumn{2}{|c|}{ Male } & \multicolumn{2}{|c|}{ Total } \\
\hline & Number & $\%$ & Number & $\%$ & Number & $\%$ \\
\hline Expensive & 36 & 22.22 & 111 & 50.92 & 147 & 38.68 \\
\hline Affordable & 80 & 49.38 & 63 & 28.90 & 143 & 37.63 \\
\hline Cheap & 7 & 4.32 & 12 & 5.50 & 19 & 5.00 \\
\hline No idea & 39 & 24.08 & 32 & 14.68 & 71 & 18.69 \\
\hline Total & 162 & 100.00 & 218 & 100.00 & 380 & 100.00 \\
\hline$X^{2}=34.79$ & $p<0.05$ & & & & & \\
\hline
\end{tabular}

Table 14 shows the distribution of the features that students take into consideration when buying dairy products. When these values are examined, $26.32 \%$ of the students stated that they considered the expiration date of the brand they preferred while $27.89 \%$ of them bought dairy products. It is seen that $16.58 \%$ of the students bought dairy products by considering hygiene, $13.95 \%$ the price, $7.10 \%$ the level of fat, $3.16 \%$ general appearance of the product.

Selcuk et al. (2003) in a similar study found that $17.62 \%$ of university students took the brand into consideration when buying dairy products and $47.80 \%$ of the surveyed students paid attention to the expiration date. Studies conducted by Wilkie (1986) and Assael (1992) reported that gender, which is one of the demographic features, plays a decisive role in consumers' preferences for products and brands.

Seeing that seasonal differences might be effective on families' milk consumption, they were asked in which season they consumed most milk. On average, $47.37 \%$ of the students stated that they consumed milk in all seasons, $25.53 \%$ in the winter, $9.21 \%$ in the summer, $3.68 \%$ in fall and $2.89 \%$ in the spring. Statistically significant difference was observed between the seasons when milk was consumed and gender $(\mathrm{p}<0.05)($ Table 15). 
Table 14. Features students pay attention to when buying milk.

\begin{tabular}{|c|c|c|c|c|c|c|}
\hline \multicolumn{7}{|c|}{ Gender } \\
\hline \multirow[b]{2}{*}{ Features concerned when buying milk } & \multicolumn{2}{|c|}{ Female } & \multicolumn{2}{|c|}{ Male } & \multicolumn{2}{|c|}{ Total } \\
\hline & Number & $\%$ & Number & $\%$ & Number & $\%$ \\
\hline Brand & 44 & 27.16 & 56 & 25.69 & 100 & 26.32 \\
\hline Date of expiry & 52 & 32.10 & 54 & 24.77 & 106 & 27.89 \\
\hline Price & 17 & 10.49 & 36 & 16.51 & 53 & 13.95 \\
\hline Diversity & 5 & 3.09 & 3 & 1.38 & 8 & 2.10 \\
\hline Hygiene & 22 & 13.58 & 41 & 18.81 & 63 & 16.58 \\
\hline Fat level & 13 & 8.02 & 14 & 6.42 & 27 & 7.10 \\
\hline Other & 5 & 3.09 & 7 & 3.21 & 12 & 3.16 \\
\hline No purchase & 4 & 2.47 & 7 & 3.21 & 11 & 2.90 \\
\hline Total & 162 & 100.00 & 218 & 100.00 & 380 & 100.00 \\
\hline$X^{2}=7.621, s d=7, p>0.05(0.367)$ & & & & & & \\
\hline
\end{tabular}

Table 15. Seasons when students consume milk.

\begin{tabular}{llllllll}
\hline \multicolumn{7}{c}{ Female } & \multicolumn{7}{c}{ Gender } & Male & \multicolumn{2}{c}{ Total } \\
\hline \multicolumn{1}{c}{} & Number & & \% & Number & \% & Number & \% \\
\hline Spring & 2 & 1.22 & 9 & 4.13 & 11 & 2.89 \\
Summer & 11 & 6.79 & 24 & 11.01 & 35 & 9.21 \\
Fall & 9 & 5.56 & 5 & 2.29 & 14 & 3.68 \\
Winter & 46 & 28.40 & 51 & 23.40 & 97 & 25.53 \\
All seasons & 71 & 43.83 & 109 & 50.00 & 180 & 47.37 \\
No-consumption & 23 & 14.20 & 20 & 9.17 & 43 & 11.32 \\
\hline Total & $\mathbf{1 6 2}$ & $\mathbf{1 0 0 . 0 0}$ & $\mathbf{2 1 8}$ & $\mathbf{1 0 0 . 0 0}$ & $\mathbf{3 8 0}$ & $\mathbf{1 0 0 . 0 0}$ \\
\hline$X^{2}=10.899, s d=5, p<0.05(0.053)$ & & & & \\
\hline
\end{tabular}

\section{CONCLUSIONS}

In the present study, the aim is to determine drinking milk consumption behaviors of students at Erzincan Binali Yildirim University. To achieve this aim, 380 students were surveyed, and Chi-square analyzes were conducted. The results of the analysis suggest that $21.10 \%$ of the students studying in different units of Erzincan Binali Yildirim University consume milk regularly while $78.90 \%$ do not consume milk regularly. The same is also valid for students with high income. In addition, the majority of students who consume milk regularly prefer processed milk. The results also showed that the majority of the students consumed milk because of its nutritional value. Considering the results, it is argued that activities that are of great importance in balanced and adequate nutrition, which encourage students to drink milk, should be organized.

In order to increase milk consumption, large-scale campaigns should be made throughout the country to provide accessibility to consumers of all age groups. Instead of carbonated beverages, milk should be available in mass consumption areas and its consumption should be encouraged. In order to support the habit of drinking milk, projects should be developed as of childhood. Informative activities should be carried out on the benefits of milk, public spots should be established in the visual media and more conscious consumers should be intermediary. 


\section{REFERENCES}

Akbay, C., and Tiryaki, G. Y. (2007). Consumers' packed and unpacked milk consumption behaviour: a case study in Kahramanmaras. KSU J Sci Eng, 10(1), 89-96.

Anonymous, 2019a. Livestock statistics, http://www.tuik.gov.tr. html (Accession Date: 05.08.2019).

Anonymous, 2019b. National milk council sector report-2018, http://www.ulusalsutkonseyi.org.tr/ana/default. asp. html (Access Date: 05.08.2019).

Assael, H. (1995). Consumer Behavior and Marketing Action. Boston, USA: New York University, PSW-Kent Publishing Company.

Ayar, AH. and Demirulus, H. (2000). The determination of consumption patterns of milk and milk products of school age youth. The Food, 25 (5): 371-376.

Henry, C., Whiting, S. J., Phillips, T., Finch, S. L., Zello, G. A., and Vatanparast, H. (2015). Impact of the removal of chocolate milk from school milk programs for children in Saskatoon, Canada. Applied Physiology, Nutrition, and Metabolism, 40(3), 245-250.

Collins, M. (1986). Sampling (Editör: Worcester, R.M., and Downhom, J., 1986). Consumer Market Research Handbook. Elsevier Science Publishing Company Inc.

Celik, Y., Karli, B., Bilgic, A., and Celik, S. (2005). The level of milk consumption and consumption pattern of consumers in Sanliurfa urban areas. Journal of Agricultural Economics, 11(1), 5-12.

Cetinkaya, A. (2010). A survey of the consumption habits of milk and milk products among the students in Kafkas University. Atatürk University Journal of Veterinary Sciences, 5(2), 73-84.

Kim, H. D., Kim, D. S., and Kim, S. S. (1994). Milk and beverage preference of college students. Journal of the Korean Society of Food Science and Nutrition, 23(3), 420-428.

Karakaya, E., and Akbay, C. (2013). Consumer consumption habits of milk and milk products in Istanbul province. Journal of Faculty of Agriculture, Uludag University, 27(1), 65-77.

Niyaz, O. C., and İnan, İ. H. (2016). Determination of milk and dairy consumption levels of consumers in TR22 South Marmara Region. ÇOMU Journal of Faculty of Agriculture, (In Turkish) 4(2), 713.

Onurlubas, E., Dogan, H. G., and Demirkiran, S. (2015). Nutritional habits of university students. Gaziosmanpasa University Faculty of Agriculture Journal, (In Turkish) 32(3), 61-69.

Onurlubas, E., and Cakirlar, H. (2016). A research on determining the factors affecting consumers' milk and dairy consumption. Journal of Cankiri Karatekin University Institute of Social Sciences, (In Turkish) 7(1), 217-242.

Para, G., Ulger, İ., and Kaliber, M. (2018). A research on determining milk consumption habits of Erciyes University students. Igdir University Institute of Science Journal, (In Turkish) 8(1), 329339.

Selcuk, S., Tarakci, Z., Sahin, K., and Coskun, H. (2003). Dairy products consumption habits of Yuzuncu Yil University undergraduate students. Yuzuncu Yil University Journal of Agricultural Sciences, (In Turkish) 13(1), 23-31.

Sahin, K., Andic, S., and Koc, S. (2001). Families' behaviour of purchase and consumption of herby cheese and dairy products in urban area of Van province. Yuzuncu Yil University Journal of Agricultural Sciences, 11(2), 67-73.

Sahinoz, S., and Ozdemir, M. (2017). Milk and dairy consumption habits of university students and affecting factors. Gumushane University Journal of Health Sciences, (In Turkish) 6(4), 106-112. 
Seker, I., Seker, P., Sahin, M., Ozen, V. S., Akdeniz, A., Erkmen, O., Kıslalioglu, I., Sargin, G., and Dogu, G. B. (2012). Milk consumption habits of consumers in the central district of Elazig Province and determining the factors affecting these habits. Journal of FU Health Sciences Veterinary, (In Turkish) 26(3), 131-143.

Simsek, O., Cetin, C., and Bilgin, B. A. (2005). Research on determination of the drinking milk consuming habits and the factors affecting these habits in Istanbul Province. Journal of Tekirdag Agricultural Faculty, 2(1), 23-35.

Simsek, B., and Acikgoz, İ. (2011). Determination of fluid milk consumption habits of the students of Suleyman Demirel University. Yuzuncu Yil University Journal of Agricultural Sciences 21(1):1218.

Simsek, B., and Acikgoz, İ. (2011). Evaluation of university students' dairy consumption habits. Igdir University Institute of Science Journal, (In Turkish) 1(3), 57-62.

Tarakci, Z., Selcuk, S., Sahin, K., and Coskun, H. (2002). A study on the habits of fluid milk consumption of the students at the University, Yuzuncu Yil University, Faculty of Agriculture. Journal of Agricultural Science, 13(1), 15-21.

Tarakci, Z., Karaagaç, M., and Celik, O. F. (2015). Determination of fermented dairy product consumption habits in Ordu city center. Academic Journal of Agriculture, 4(2), 71-80.

Wilkie, W.L. (1986). Consumer Behavior. New York, USA: University of Florida.

Yalcin, M., and Argun, M. S. (2017). Determination of milk and milk products consumption habits and affecting factors of Bitlis Eren University School of Health students. Bitlis Eren University Journal of Science, (In Turkish) 6(1), 51-60.

Yalcinkaya O, (1999). Animal food consumption structure in Erciş District of Van Province. Yuzuncu Yil University Graduate School of Natural and Applied Sciences Department of Agricultural Economics, Van. Master Thesis (Printed). 